\title{
Kakha Gabunia
}

Ivane Javakhishvili Tbilisi State University

\section{Language Situation in Modern Georgia 1. Kartvelian Languages}

\begin{abstract}
The article displays main aspects of the large-scale works made by Frankfurt am Main Goethe Institute in the framework of the project "Sociolinguistic Situation in Modern Georgia" (financed by Volkswagen Foundation). 42 scientist from 12 Georgian scientific establishments took part in the project.

First part of the article shows the cumulative results of the researches made by Kartvelian Language Group in 2006-2008.
\end{abstract}

\section{Introduction}

The term "language situation" means overall configuration of language use in given time on given place and includes such data as: how many and which languages (dialects) are used in a given area, how many people speak them, in which situation, what attitudes and feelings the members of given community have towards this languages (J. Ferguson, 1971, p. 157).

\subsection{Language Policies}

A language policy is an official action which tries to intervene in the area of functioning (e.g. Writing system, choosing of official language etc.) Of any type of a language (state, regional, minority, foreign etc.), or in the parts of the educational system that are connected to these languages.

Citizens or citizen groups can implement a language policy voluntarily on state level or in a private sector. Influence upon languages takes place in the context of spe- 
cific social situations or events to which it belongs.

A language policy consists of several components: national concept, educational goals, actors (politicians, public persons, political party activists, members of trade unions etc.) and intervention levels (legislative, regulatory etc.).

To acknowledge the political nature of language and language teaching is a prerequisite for any action in this area, since technical difficulties (structural, administrative, financial etc.), that should be solved by government's individually or cooperatively, cannot be solved until issues related to these principles are not defined.

The language plays a key role in defining the affiliation of certain social or regionethnical unity. The feeling of the value of the Native language is a fundamental component of comprehending one's role in community. Since language is a visible sign of group affiliation, it can easily become the symbol of this group. Language can be a valuable resource for an individual or a group, which needs to be preserved and be taken care of, which is reflected in the attitudes toward this language (Ó Riagáin Pádraig \& Lüdi Georges, 2008, p 29).
This is the reason why we use the term "language variety" to avoid the use of term language, which is always means thinking with values. Any definition of language varieties are based on external factors and not the real (linguistic) characteristics of the given variety.

Language, like any Phenomenon, has two natures, is considered in two aspects:

One is its inner, immanent nature, defined by its form and semantic system and structures. Manifesting of these structures in their own dynamic, defining of causeand-effect relations between them, defining the regularity between their changes and development - this is the specific task of linguistics.

Second aspect is the pragmatic, applicational side of a language. To define is applicational side of a language, learn the applicational function of the language, defining the social values of a language, researching connection of language towards social processes and its influence on these processes, basically studying the social causes of the creation, existence and development of a language - this is the task of sociolinguistics. (B. Jorbenadze, 1980). 
1. 2. Language Nomenclature: Native language/mother tongue, foreign language, second language

Language nomenclature is the subject of academic and political debates (the term "language" included). It is desirable to develop terminology for at least defining language types: Native, foreign, second etc. But, defining all the categories objectively is impossible.

There is an interesting relation in Georgian reality between terms "native language" and "mother tongue".

In European linguistics words/phrases with semantic of "mother" are often used (Eng. Mother tongue, Germ. Muttersprache, Swed. Modersmål, Fr. La langue maternelle, Sp. La lengua materna, Geo. coৎosj6s etc.); same meaning (practically a synonym) is conveyed with the term "native language (Eng.: Native Language, Rus. родной язык,

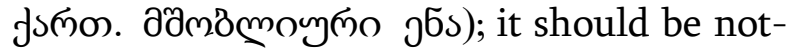
ed, that there was a serious discussion in Germany about changing the historical term "mother tongue" to more "adequate" translation as "native language" (or - basis language). In Germany the motivation was completely different - the accusations of Nationalism (G. Ramishvili, 2000. 70); there is a really exceptional situation in Georgian reality in this aspect.

Dedaena (Georgian: Mother Language) is defined as an own language, which defines the identity of a person, whether he/she learned it from the childhood or not. As stated above, European languages also have lexemes with similar content and form, but due to historical reality, they have a rather diminutive feel and were traditionally connected with women, children and other illiterate members of the society; while in Georgian it means the main language (G. Ramishvili, 2000, p. 9; Z. Kikvidze, 2004, p. 206-212; N. Dennison, 1986, D. Pattanayak, 2003, p. 23-28).

In the definition of mother tongue the social purpose is highlighted: "Dedaena means main language and not someone's language (it is the subject of sociology, not individual psychology)" - see. G. Ramishvili, 2000, p.9); "Dedaena is the language of the culture created by the ancestors. As a worldview system, it unites several generations. Dedaena is the main language, not necessarily the language of a biological parent (T. Futkaradze, 2005, 324).

It seems that this is an attempt to give the term "dedaena" special functions (such 
that, for example, English "mother tongue" lacks). This has certain objective Precondition a notable fact is that at the end of the XIX century a textbook by I. Gogebashvili with this name (Deda Ena) was published, which the whole Georgian nation used to start learning the native language. So the opinion common among Georgian scientists - that literary Georgian language is the same as Dedaena - is not accidental (T. Futkaradze, 2005, 61).

If we consider the traditional understanding of native language (the language using which a child understands and assimilates linguistic "rules" in his immediate environment and, as well as rules of communicational behavior), then it naturally becomes impossible to consider literary language being the same as native language (Dedaena); thus it is clear that the term Dedaena has already acquired additional functions, which are not characteristic for the term native language.

Thus, in this article we deliberately avoid the use of terms "native language" and "dedaena/mother tongue" and use the term first language instead - the language that a person learns in early years naturally, main- ly in the family, among parents, without any instructions.

The difference between terms second and foreign languages must be noted. Second language is any language one learns after first or native language. The accent here is on the importance of geographical or social environment; this means, that this language is learned in an environment where it is spoken. It is not a so called foreign language. Second language. Second language definition not only incudes the sequence of learning, but also highlights the sociolinguistic status of the language variety.

Foreign language is a language the use of which does not go beyond the bounds of a classroom. In-depth learning of such a language is difficult. It is not easy to learn a foreign language as well as native, or even second one.

It is necessary to differentiate between the statuses of second and foreign languages: the term foreign languages are often used to refer to language varieties, learning of which can have less motivation: namely, the learners are not in contact with these language varieties, or use the, only in virtual or limited forms (cinema, television, visits to countries in which they are used etc.). be- 
cause of this, the learners may not understand their own needs of the foreign languages - for them they are just school subjects, the achievement of which is not a factual acquisition, but the assessment (tests, exams); this is the main difference between second and foreign languages: second language is acquired, assimilated by the learner; foreign language is learned as a subject (this causes the difference between methodological approaches and teaching strategies).

\subsection{State language; dominate language; lan-} guage minorities

State language is a language variety which has a role of communication language between citizens and state (state departments, legal system, schools) sanctioned by constitution or other legal instruments. This means that citizens can use any language variety in private communication. But, in most cases, official language is the native language for the part of the population significant either in number or socially. Although, for example, in the former colonies of western states this role can be played by the language of the colonizer, which is not native to any of the aboriginal groups.
In national states the official language can become a factor of identity or the membership of society. State language does not always match citizenship (if you speak English, it does not mean you are a citizen of Australia, Belgians speaking French and Belgians speaking Flemish are citizens of the same state etc.). Because of this, the term state language is more emotionally charged than the term official language (Development of language education policies in $\mathrm{Eu}-$ rope - guiding principles, 2008, p.64).

Term dominant language describes a language variety with higher legal or social status compared to other varieties on the given geographical territory. The superiority can apply to a whole state or to one region of it. This superiority is measured not only by the number of a speakers. The place given to a variety with such a status by the society tells us that we should research how appropriate the allocation of such space is and what the characteristics of this space are.

Language minority is a language which might be spoken by minorities on the part of national territory and which might even have an official status, but it might not be the status of official or legal language. 
The term language minority refers to language varieties which are used by certain groups: these groups may consider themselves to be different due to territorial settlement, religion, lifestyle or any other characteristic and strengthen or regulate their difference within the bound of greater society.

The language minority status of several societies does not correspond to quantitative criteria: on certain geographic territories or societies such language varieties may be widespread; but the status belongs to rights which these groups do not possess: the use of this language on court, in production of legal or administrative documents, as a teaching language in education (primary school as well as university), in functioning as a language of national media, street signs etc. Regional and Minority language Charter lists social life sectors, in which the use of such language varieties participant states takes responsibility to support.

\subsection{Language self-identification and hetero- identification}

Language, along with religion and territory is one of the self-identification resources. Although, in the $21^{\text {st }}$ century, a state cannot be formed using the same model as in the $19^{\text {th }}$ century: today it is impossible to perceive statehood based only on common historical values as religious inheritance, individual moral and individualism or common political ideals, which are still far from usual lives of people.

Studying the issues of identification with language must take place only in the context of identity formation. To study the subject in this context is important, since the language is an identification mechanism and, at the same time, an important factor for an individual in developing the internal and externals factors of belonging to a certain group.

Identification with language is a widespread form of cultural identification, since the language is generally considered to be a sign that an individual belongs to a certain group. But to use only the language as an identification characteristic is an attempt to diminish the real linguistic diversity (Beacco Jean-Claude, 2008, p. 13).

Identification language, be it selfidentification or hetero-identification, is usually the native language. On the first glance the term "native language" seems to be quite unambiguous, but actually it is not 
such a simple term (see above). In practice, the first language for a child is the language of mother as well as farther. If parents have same native language or a language they communicate in, there seems to be no problem. But sometimes the parents speak more than one language, which they use to communicate, and these languages are not always the native (first) languages for them. One thing that is clear is that "native language" is the most accessible for identification purposes, since it gives the ability to easily transmit the identification with genetic line to the descendants.

It is often assumed that the identification language is self- as well as heteroidentification is the state (national) language. Recently, this model of identification is becoming increasingly popular.

Language intensifies the feeling of being different from others, the difference of language is symbolized with the absolute identity of specific groups. This selfcategorization has become traditional on European scene, which was spread with historic terms such as: national minority/nationalities and nations. This ethnic concept (as it is often called) of nation definition, which is drastically different from the civil concept, has been and still is the basis of official and normal categorization, which perceives national and civil unions as one and the same and connects national union to having same language (Beacco JeanClaude, 2008, p. 19).

\section{About the Project "Sociolinguistic situa- tion in modern Georgia"}

There are several languages represented in Georgia. Some of them are IndoEuropean (Greek, Russian, Armenian, Ossetian, Kurdish, Ukrainian), some are Altaic or Turkic-Tatar (Azeri), Uralic (Estonian in Abkhazian - villages Estonka and Salme), some are Semitic or Arameo-Syrian (separate villages in Georgia) and IberoCaucasian language Family, consisting of for Groups: Kartvelian, Abkhazo-Adyghean, Nakh and Dagestani (see appendix \#1).

One of the varieties of Kartvelian languages - Georgian language - has the status of state language; other Kartvelian languages are unwritten (with no written language).

In 12-14 December 2003 an international conference with the support of Volkswagen Foundation, called "The sociolinguistic situation of present-day Caucasia" was held, in 
which caucasologist from around the world took part; on this conference an issue was raised - a conduction of a sociolinguistic study based on modern methods, which would result in a complete analysis of existing language diversity in Georgia.

On the February 16 2006 the project was signed (financed by - Volkswagen Foundation; project authors - I. Gippert, M. Tandashvili; Goethe University Frankfurt am Main); 8 Scientific-learning establishments and 42 leading scientist took part in its conduction; in the correspondence to the tasks in the framework of the project 6 Workgroups were formed:

I. Georgian Literary Language Group;

II. Kartvelian Languages Group;

III. Caucasian Languages Group;

IV. Non-Caucasian Languages Group;

V. Georgian Dialects Group;

VI. Migration and Digital Processing Group.

The goal of the project was on one hand to study the modern status and functionality aspects of Georgian as a state language; and, on the other hand, the sociolinguistic analysis of the languages (speaking codes) of ethnic and linguistic groups living in Georgia. Due to complexity of the issue, the project was of a multidisciplinary nature: one im- portant part of the project was to study the migrational processes and following language changes in Georgia during the last 100 years.

Because of the research goals, the project included not the internal structural analysis of languages themselves, but the description of how people from social groups used these languages. The internal structure of a language is accepted as existing data and is not analyzed; our interest was to find out in which areas of life the languages under our study were used; what is the relation among them in respect to status and functionality; which language is "leading", so to say, or which is the main (although unofficial) communication mean between different ethnic groups; which languages are used with religious, domestic or everyday life functions.

It is quite difficult to answer these questions and the research in this direction has only begun recently in Georgia. It must be said that the accent in the works about this problem were mainly on diachronic sociolinguistic, which studies language development process related to social development. Due to different objective or subjective reasons, the development of synchronic socio- 
linguistic, especially during the Soviet Era, was not supported.

\subsection{Research Methods}

There is a special methodology for studying language functionality: desk research, social surveys with questionnaires, in-depth interviews etc. The study of languages with legal (state, regional, and minority) status is based on reviewing constitutional and normative acts and questionnaire researches, while surveys with questionnaires are used for languages without status to find when and in which situation in which context - one uses a certain language. Determining such characteristics of an individual as nationality, religion, native language, is an unambiguous human right, anchored in International Convention of Human Rights and there is only one approved method of researching them scientifically - surveys with questionnaires.

The questionnaires for sociolinguistic censuses, when asking questions about language issues, are usually focused on one hand, on the first (native) language and, on the other hand - on another, non-native language used every day, spoken at home, with neighbors, when communicating with government agencies, in school or work etc.; there are very few censuses, which include the questions that would reveal complete information about the languages the respondent speaks. We think the questionnaires developed in the framework of this project are quite informative in this aspect answers

Questionnaires should have a place where the respondent can reflect more information and the question should not have only one question, but given the option to reflect different answer and thus the diversity of language functions ( especially in the diversity of the association of an individual to certain groups).

This statistic custom can also be seen in the process of statistical calculation; for example, when counting the number of certain minorities in a region, there is this tendency: the language minorities are identified with only one language, with native language, and the statistic gives no information about the level the subject speaks the native language; as well as to what purpose, in which areas, this language is used. It is a sad reality that the approach of identification with one language is dominant in most of the societies. Thus, this kind of a 
defect can also be seen in sociolinguistic studies.

Multi-language repertoire of an individual, as stated above, consists of different languages he/she acquired with different ways (childhood, teaching, independent learning etc.) and different skills gained in the process (spoken language, reading, writing etc.) on different levels. These languages may have different functions and purposes; for example, communication within the family, communication with neighbors, in learning process or at work. Language is a basis which unites a group according different cultural characteristics around the identification language. Language repertoire is $\mathrm{di}^{-}$ verse: some groups have identical language repertoire, which is caused by historic or geographic reasons and the individual chooses on, symbolic language, around which the group is formed. Of course, this doesn't mean that he/she loses other languages from the repertoire. They are used masked or with self-censorship, meaning the languages are not self-identified with; but these languages are used according to circumstances and situations.

\subsection{Kartvelian Languages}

Kartvelian languages are Georgian, Zan (same as Colchian, or Megrelian-Laz languages) and Svan; some scientist consider Megrelian and Laz languages to be separate languages (G. Kartozia, Z. Sarjveladze, H. Fähnrich etc.). In last years the status of Kartvelian languages (Megrelian-Laz and Svan) has become a subject of debates; a part of scientist considers them to be dialects of Georgian.

In linguistics the definition of dialect is:

“Territorial, temporal or social variety of a language, used by relatively limited number of people and is different with its structure (phonetic, grammar, lexical, semantic) from language standard, which itself is the socially most prestigious dialect (B. Jorbenadze, 1989, p. 8). A dialect must be defined as a language speaking variety spread on a certain territory or in certain ethnic, social, professional or age groups. So we have territorial, ethnical, social and professional dialects (B. Jorbenadze, 1989, p. 8).

Of course, a dialect can turn into a language, i.e. develop as an independent language system. At that point is changes qualitatively - quantitative differences become 
qualitative differences (B. Jorbenadze, 1989, p. 10).

The relation between language and dialect can defined in following way: the prerequisite for admitting that language varieties or dialect belong to the same language is that they form the same continuum. (W. Boeder, 2005, p. 218).

In sociolinguistics dialect is defined in applicational (practical) light; thus, its linguistic status, as a rule, is not considered; this means that the description is according extalinguistic (and not immanent) signs:

The term Dialect in sociolinguistics is sometimes used referring to regional and language minorities (in other words, its linguistic immanent essence is ignored): generally, they are factual varieties belonging to national or federal territories. They belong to local population; for example, in contrast to newly settled migrated society. They do not necessarily belong to the same language gamily, like dominant/official varieties.

Dialect is also used in relation to the use of national or official languages. Varieties can be sociological (age groups, education level, formality of communication etc.) and/or territorial in origin. Notable are, for example, deviations in pronunciation or lex- ical peculiarities. They cause national language norm problem, from which they look “crooked". Varieties can crystalize and give identity substance for creation of new minority varieties (namely, in one generation or professional group).

Such language varieties are quite stable they can even have their own written language: literature, dictionaries and base grammar. Because of this they can easily become the subject or the mean of instruction. They are united by the fact that they do not have any official or special status, but their recognition buy the rest of national society is ambiguous. This recognition, by the way, depends on the ability of mutual understanding between the given language variety and official/dominant variety as well as on cultural closeness between the group and other citizens. These language varieties are the development of fundamental feeling of belonging to a group as well as its clearest expression. In several cases the opinion of regional belonging is not the same as national belonging, but it can create a radical form of separation from national political society. Because of this a part of society's opinion can consider regional and minority languages to be a danger against nation. 
This is exactly the kind of "danger" a part of Georgian linguists consider the status of Svan and Zan languages to be. In last years this kind of opinion has appeared: "the differentiation between language and dialect cannot be done solely in the area of linguistics; no language with a cultural tradition is named a language based on linguistic signs: no one has yet defined the margin after which the differences between related language units turn from quantitative to qualitative - a variation of a system becomes a new system" (T. Futkaradze, 2003, p. 119); thus, "the status of existing languages are, as a rule, defined by ethno-cultural and political-religious signs" (T. Futkaradze, 2003, p. 70);

It is an attempt to politicize the issue to categorically assert "as a rule, one nation (Ethnically speaking) has one mother tongue" (T. Futkaradze, 2003, p. 62); “one nation (ethnic unity) indicates one language” (T. Gvantseladze, 2003, p. 600).

We do not have means to deeply analyze this opinion, but we will still speak about the problem in several words.

Generally, same object (in our case - language) can become the subject of a study for several fields; a clear example for this is the existence of aside spectrum of natural sciences: the same natural event are studied from completely different angles (chemistry, physics, botanic, biology etc.). It is the same with the language: we must observe the principle of immanent definition. When speaking about the origin of a certain language, its relative languages - we must use the rules and terminology developed in the heart of historical-comparative linguistics; even A. Meie wrote, that "the only linguistic classification which is valuable and useful is a genealogical classification, based on the history of languages (A. Meie 1924, p. 1). Qualification as a language happens according systematic identity and differences - this is an axiom for linguist and other approaches are beyond the area of linguistics. Thus, the definition linguistic terms (language, dialect etc.) and their relation in linguistics are possible only with linguistic criteria, inclusion of extralinguistic concepts and criteria can only cause chaos (A. Oniani, 2003, p. 136).

Sociolinguistics studies language(s) functionality on synchronic level; its purpose is not and has never been the definition of the linguistic status of an object. It is clear that the status of certain units will be different 
for historical-comparative linguistics from what was "made a rule" by sociolinguistics due to different extralinguistic factors. We think the opinion stated by B. Jorbenadze is correct: "in linguistic (to be exact, linguistic) view Megrelian-Laz and Svan languages are brother-languages to Georgian, but in ethnic-political (again, to be exact - sociolinguistic) view they have the same status as dialects (B. Jorbenadze, 1989, p. 36).

This issue is interesting from the angle of self-identification: Are Megrelian-Laz and Svan languages or dialects? - this was one of the questions asked to the respondents when making in-depth interviews, although this was not and could not be the once-andfor-all solution of this problem. It was just interesting what kind of attitude people (who have nothing to do with linguistics) have towards Megrelian-Laz and Svan languages and their roles.

Usually, Megrelian-Laz and Svan are regional languages or dialects of the Georgian language (the issue of self-identification when qualifying as a regional language will appear on its own, the accents is on being Georgian).

\subsection{Analysis of sociolinguistic question-} naires

The main part of the sociolinguistic questionnaires created in the framework of the project is the question-group created to determine the area of use of language repertoire by the respondents. It is clear that in the condition of diglossia Kartvelian languages are different in function: the use area of Megrelian-Laz and Svan does not go beyond the scope of everyday communication (See T. Bolkvadze, 2007, 223). According to previous studies made in different social groups, this area of the scope of Megrelian language use are defined: at home, in oral folklore, markets, at funerals, at a table, during the free-time at school, in Kindergartens, garmers while working, during the free-time at the University, during the private correspondence (verified by the article of T. Bolkvadze-2007, p. 224).

In our questionnaire we took following impotant factor into account: as it is known, in sociolinguistics spoken and written languages are differentiated: these are designations of different language forms and depend on which area used (speakins/spoken language or writing). These two forms of communication have different characteris- 
tic: structure, organization, register (Development of language education policies in Europe - guiding principles, 2008, p.134137); most importantly, spoken language has usually less social status and its written form can not (or does not) develop. Thus, the questions were grouped in 3 blocks:

1. Questions related to spoken (at the same time, informal) communication (speaking and listening skills) of the respondents;

2. Questions related to writing and reading skills of the respondents and reflects the repertoire of written communication.

The questions of first block:

a. The use of language at home: which language do you/did you use to speak to your father?; which language do you/did you use to speak to your mother?; which language do you/did you use to speak to your siblings?; which language do you/did you use to speak to your spouse?; in which language do/did your parents speak?; in which language do/did your grandparents speak?; in which language does/did your spouse speak?; in which lan- guage/languages did your grandparents speak before entering the school?; in which language/languages did your grandparents speak with each other entering at home?; in which language do you pray alone at home?; in which language do you pray in the church?; in which language do you get angry, curse?; in which language do you count(calculate)?; in which language do you speak to yourself when alone?; in which language do you dream?; what language do you speak in your dreams?

b. The use of language in everyday life (in community): in which language do your speak to your neighbors?; what language do you have to use most often in your village (neighborhood)?; in which language do you have to speak most to the elders of your village?; in which language do/did you have to speak in market?

c. The use of language with official structures:

in which language do/did you have to speak to your coworkers most of- 
ten?; in which language do/did you have to speak to regional administration most often?; in which language do/did you have to speak in hospital most often?; in which language do/did you have to speak at school with the teachers most often?; in which language do/did you have to speak are bus/railway station checkouts most often?

With the passage of time, the language situation did and does of course change. Centuries ago the Megrelian lower social circle members knew Georgian language practically only due to the Church, Georgian was the language of the religion and this served as a language-binder and connector of Georgian tribes - thus, it cannot be said that Megrelian farmer centuries ago did not speak Georgian because he did not need it - he was not disconnected from common Georgian reality, national roots. The literacy problem remained till $20^{\text {th }}$ century for the whole Georgia (and not only Samegrelo or Svaneti). But Georgian was for him not a foreign language (like, for example, Russian, which he heard more intensely than Georgian, e.g. in XIX century). It was and still is classified as second language
("Second native language", as respondents often name it).

Language situation in Samegrelo even for several decades ago was quite different from today - the trend has clearly evolved in favor of Georgian language.

We present the general conclusions: almost half of questioned respondents perceive Megrelian-Laz/Svan language as the first language (46.4\%); for a large part of respondents the so called "symbolic language" ("dedaena" [mother tongue] - Georgian) is the first language (43.8\%); $6.8 \%$ cannot make a clear identification and represent a clear diglossia.

The questions of the first block in the questionnaire were general; the analysis of the answers of the second block questions were more interesting, since they are about writing and reading skills. It is interesting since Svan end Zan (Megrelian-Laz) languages do not have their own written language, so they successfully use literary language to reflect reading and writing language functions. The literary language is based on one of the Branches of Kartvelian languages - the Georgian language. In other words, Megrelian and Svan population mostly uses first language (Megrelian, Svan) 
in the area of spoken language (speaking, listening), while "filling" the gaps of reading and writing with the literary Georgian, which is strengthened by its status as common Georgian language. Here must be not- ed, that Georgian literary language also gas a "prestigious" status and covers wide areas in spoken language component as well.

Schematically, this situation can be shown in this way:

\begin{tabular}{|c|c|c|c|}
\hline & Spoken Language (Listening, Speaking) & Reading & Writing \\
\hline Svan, Megrelian & + & & \\
\hline $\begin{array}{c}\text { Literary Georgian Lan- } \\
\text { guage }\end{array}$ & + & + & + \\
\hline
\end{tabular}

A separate subject is the Laz language (a dialect of Zan, together with Megrelian): a small part of Lazs is settled on Georgian territory and their language situation is identical to the schema above. As for the Lazs living in Turkey - their selfidentification is quite different and it needs of be researched separately (the purpose of this article is the sociolinguistic analyze of Georgia).

The incomplete list of questions from second block:

In which language/languages do you read journals and newspapers?; do you think it is necessary for press to be published in Megrelian-Laz/Svan languages?; if not, why?; which language/languages are the books you read published?"; “Do you know any writer who writes/wrote in MegrelianLaz/Svan?; "do you have any books published in Megrelian-Laz at home?"; “in which language do you write private records?”; "in which language do you write letters?"; "in which language do you take notes?".

Major part of the respondents (up to $80 \%$ ) has not even heard of books published in Megrelian (Svan) languages ("Vefkhiskhaosani" translated in Megrelian, folkloric material, several publications of Zan-speaking poets). A part confuses something written on Zan language with Zan written language ('I don't think it has ever been published, there is no written language for these languages"; there is no Megrelian written language"; 
"there is no Svan written language" etc. the are written as comments.

On the question- "do you think it is necessary for press to be published in Megrelian-Laz/Svan languages? - 72\% gave negative answers. The answer about education language is also unambiguous: only 6 respondents said they wished for their children to receive education in Megrelian-Laz language; 4 respondents - in Svan language (together only $1 \%$ of the respondents).

In fact, the education language for respondents is the same as written communi- cation. The answers to the questions in direction also show clear separation of the functions of the Georgian as education language and the Megrelian-Laz and Svan languages as communication codes (likely as a self-identification instrument). This is supported by the fact that majority of respondents (90\%) answered positively when asked whether their children should be able to speak Megrelian-Laz/Svan language. 


\section{References}

A. Arabuli, 2003 - Avtandil Arabuli, Einige Eigentümlichkeiten der Verwandtschaftsterminologie in den ostgeorgischen Bergdialekten, Kaukasische Sprachprobleme, herausgegeben von Winfried Boeder, bis, 2003.

A. Oniani, 2003 - language and dialect (Kartvelian dialects or Kartvelian languages?!), Issues of linguistics \# 1, Tbilisi 2003.

А. Мейе, Введение в сравнительной изучении европейских языков, М-Л, 1938.

Abkhasian-Russian Dictionary 2005 - Abkhasian-Russian Dictionary, II, Sokhumi, 2005, 287289

Arn. Chiqobava 1938 - Arn. Chiqobava Laz-Megrelian-Georgian comparative dictionary, Tbilisi, 1938.

Arn. Chiqobava, 1936 - Analysis of Laz Grammar, Tbilisi, 1936.

B. Jorbenadze, 1989 - B. Jorbenadze, Georgian Dialectology, I, Tbilisi, 1989.

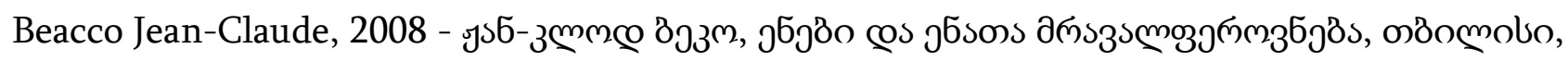
2008.

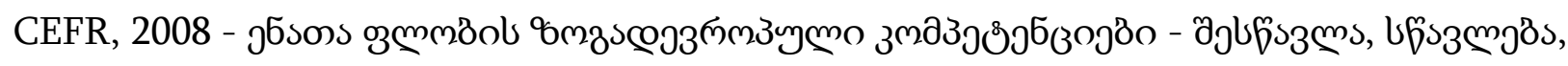

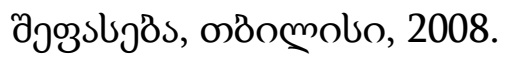

Ch. Ferguson, 1959 -Ferguson Ch. A., Diglossia in Word, 15, 1959.

Ch. Ferguson, 1971 - Ferguson Ch. A., Language Structure and Language Use, Stanford, 1971.

D. Pattanayak 2003 - Pattanayak, D. P. Mother tongues: the problem of definition and the educational challenge. Towards a Multilingual Culture of Education, ed. by A. Ouane. Ham-burg: UNESCO Institute for Education, 2003.

G. Ramishvili, 2000 - G. Ramishvili, Dedaena Theory, Tbilisi, 2000.

H. Kloss - Kloss, H. Types of multilingual communities. A discussion of ten variables. Sociological Inquiry, 36 (2), 1966:

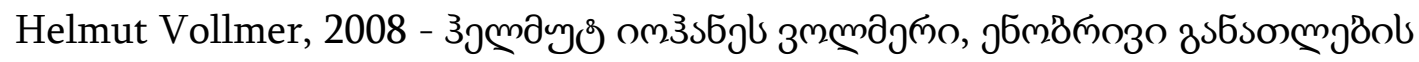

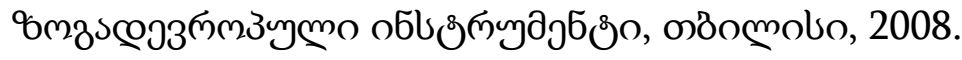


J. Fishman, 1968 - Fishman, J. A. Sociolinguistic Perspective on the Study of Bilingualism. Linguistics, 39, 1968.

J. Jardel 1982 - Jardel, J.-P. Le concept de 'diglossie’ de Psichari à Ferguson. Lengas 11, 1982.

Multilingual education in Europe, Tbilisi 2008.

N. Dennison 1986 Dennison, N. (ed.). Grazer Linguistischer Studien, 27, 1986;

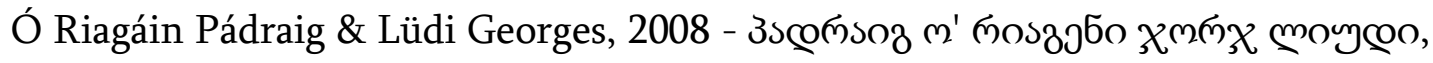

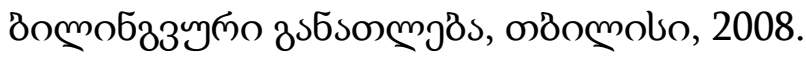

T. Boklvadze, 2007 - T. Boklvadze, Kartvelian Diglossia: coll: Georgian literary language issues; Tbilisi, 2007.

T. Futkaradze ,2003 - T. Futkaradze, related language unit qualification problem and Georgian dialect grouping issue, Issues of linguistic, \#1, Tbilisi, 2003.

T. Futkaradze, 2005 - T. Futkaradze, Georgians; Tbilisi, 2005.

T. Gvantseladze, 2003 - T. Gvantseladze, is д১ guage? Issues of linguistics, \# 2, Tbilisi 2003.

U .Weinreich, 1968 - Weinreich, U. Languages in Contact: Findings and problems. The Hague: Mouton, 1968.

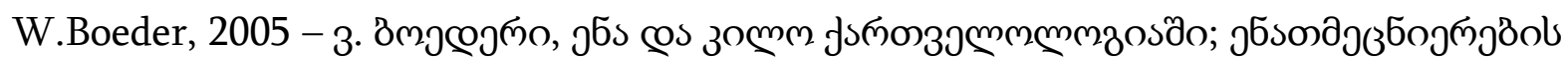
uszoombjöo, \# 1-2, ő̉omolio, 2005.

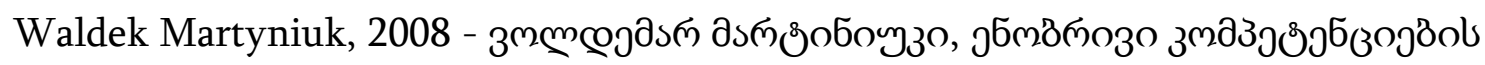

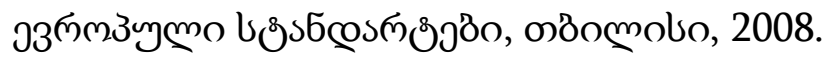

Z. Kikvidze, 2004 - Z. Kikvidze, Mother: denotation, connotation and (3бృ̊̊oon metaphors// Georgian language culture issues, book 12. Tbilisi: Georgian language, 2004. 


\section{Appendix \#1:}

\begin{tabular}{|c|c|c|c|c|}
\hline & \multirow[t]{2}{*}{2002} & \multirow[t]{2}{*}{1989} & \multicolumn{2}{|c|}{$\begin{array}{l}\text { Part in the whole pop- } \\
\text { ulation (in per cents) }\end{array}$} \\
\hline & & & 2002 & 1989 \\
\hline $\mathrm{a}$ & 1 & 2 & 5 & 6 \\
\hline Whole population & 4371535 & 5400841 & 100.0 & 100.0 \\
\hline \multicolumn{5}{|l|}{ Among them } \\
\hline Georgian & 3661173 & 3787393 & 83,8 & 70,1 \\
\hline Azeri & 284761 & 307556 & 6,5 & 5,7 \\
\hline Armenian & 248929 & 437211 & 5,7 & 8,1 \\
\hline Russian & 67671 & 341172 & 1,5 & 6,3 \\
\hline Ossetian & 38028 & 164055 & 0,9 & 3,0 \\
\hline Abkhaz & 3527 & 95853 & 0,1 & 1,8 \\
\hline Yazidis & 18329 & 0 & 0,4 & \\
\hline Greek & 15166 & 100324 & 0,3 & 1,9 \\
\hline Kist & 7110 & 0 & 0,2 & 0,0 \\
\hline Ukrainian & 7039 & 52443 & 0,2 & 1,0 \\
\hline Uzbek & 81 & 1305 & 0.0 & 0.0 \\
\hline German & 651 & 1546 & 0.0 & 0.0 \\
\hline Tatar & 455 & 4099 & 0.0 & 0,1 \\
\hline Belarus & 542 & 8595 & 0.0 & 0,2 \\
\hline Korean & 22 & 242 & 0.0 & 0.0 \\
\hline Turk (Osman) & 441 & 1375 & 0.0 & 0.0 \\
\hline Polish & 870 & 2014 & 0.0 & 0.0 \\
\hline Kurd* $^{*}$ & 2514 & 33331 & 0,1 & 0,6 \\
\hline Kazakh & 70 & 2631 & 0.0 & 0.1 \\
\hline Chechen & 1271 & 609 & 0.0 & 0.0 \\
\hline Tajik & 15 & 1193 & 0.0 & 0.0 \\
\hline Bashkir & 36 & 379 & 0.0 & 0.0 \\
\hline Moldovan & 864 & 2842 & 0.0 & 0,1 \\
\hline Ingush & 9 & 170 & 0.0 & 0.0 \\
\hline Mordovian & 19 & 415 & 0.0 & 0.0 \\
\hline Chuvash & 28 & 542 & 0.0 & 0.0 \\
\hline Kyrgyz & 113 & 225 & 0.0 & 0.0 \\
\hline Udmurt & 13 & 209 & 0.0 & 0.0 \\
\hline Lithuanian & 134 & 977 & 0.0 & 0.0 \\
\hline Bulgarian & 138 & 671 & 0.0 & 0.0 \\
\hline
\end{tabular}




\begin{tabular}{|c|c|c|c|c|}
\hline & \multirow[t]{2}{*}{2002} & \multirow[t]{2}{*}{1989} & \multicolumn{2}{|c|}{$\begin{array}{l}\text { Part in the whole pop- } \\
\text { ulation (in per cents) }\end{array}$} \\
\hline & & & 2002 & 1989 \\
\hline $\mathrm{a}$ & 1 & 2 & 5 & 6 \\
\hline Jewish & 3772 & 24720 & 0,1 & 0,5 \\
\hline Marian & 10 & 424 & 0.0 & 0.0 \\
\hline Romani & 472 & 1744 & 0.0 & 0.0 \\
\hline Lezg & 44 & 720 & 0.0 & 0.0 \\
\hline Chinese & 47 & 110 & 0.0 & 0.0 \\
\hline Persian & 46 & 123 & 0.0 & 0.0 \\
\hline Turk (Meskhetian) & 53 & 0 & 0.0 & 0.0 \\
\hline Estonian & 59 & 2316 & 0.0 & 0.0 \\
\hline Latvian & 91 & 530 & 0.0 & 0.0 \\
\hline Turkmen & 74 & 361 & 0.0 & 0.0 \\
\hline Avar & 1996 & 4230 & 0.1 & 0,1 \\
\hline Tatar (Crimea) & 15 & 615 & 0.0 & 0.0 \\
\hline American & 27 & 41 & 0.0 & 0.0 \\
\hline Arab & 44 & 76 & 0.0 & 0.0 \\
\hline Assyrian & 3299 & 6206 & 0.1 & 0,1 \\
\hline Avgan & 52 & 28 & 0.0 & 0,0 \\
\hline Circassians & 22 & 185 & 0.0 & 0.0 \\
\hline Spanish & 78 & 91 & 0.0 & 0.0 \\
\hline French & 40 & 43 & 0.0 & 0.0 \\
\hline Gagauz & 32 & 206 & 0.0 & 0.0 \\
\hline Dutch & 105 & 28 & 0.0 & 0.0 \\
\hline English & 25 & 5 & 0.0 & 0.0 \\
\hline Italian & 31 & 24 & 0.0 & 0.0 \\
\hline Laks & 210 & 426 & 0.0 & 0,0 \\
\hline Romanian & 22 & 62 & 0.0 & 0,0 \\
\hline Udi & 203 & 93 & 0.0 & 0,0 \\
\hline Hungarian & 32 & 244 & 0.0 & 0,0 \\
\hline Kabardina & 23 & 293 & 0.0 & 0,0 \\
\hline Kumyks & 42 & 155 & 0.0 & 0,0 \\
\hline Czech & 46 & 101 & 0.0 & 0,0 \\
\hline Other & 504 & 7264 & 0.01 & 0.1 \\
\hline
\end{tabular}

Note: the census of 2002 does not include the situation in Abkhazia or South Osseria, since at that time the jurisdiction of Georgian state in these regions were restricted 